\title{
UDC 141.9
}

\author{
A. M. MALIVSKYI ${ }^{1 *}$ \\ ${ }^{1 *}$ Dnipro National University of Railway Transport named after Academician V. Lazaryan (Dnipro, Ukraine), e-mail \\ telepat-57@ukr.net, ORCID 0000-0002-6923-5145
}

\section{CARTESIAN PERSONAL METAPHYSICS}

Purpose. To consider the personal nature of Cartesian metaphysics. Its implementation involves: a) outlining methodological changes in the philosophy of the twentieth century; b) analysis of ways to interpret anthropological component of philosophizing in Descartes studies; c) appeal to Descartes' texts to clarify the authentic form of his interpretation of metaphysics. Theoretical basis. I base my view of Descartes' legacy on the conceptual positions of phenomenology, existentialism and hermeneutics. Originality. Based on Descartes' own concept of teaching, the author substantiates the personal nature of Cartesian metaphysics. Important prerequisites for its comprehension are attention to the ethical motive as the driving force of philosophizing and recognition of the importance of the poetic worldview. The idea of the basic role of poetics finds its meaningful confirmation in the texts of the philosopher, who interprets the main areas of philosophy (science, morality and medicine) as the forms of art. Conclusions. Based on his own vision of anthropology and metaphysics as the forms of completion of the revolution initiated by Copernicus, the author defends the idea of the constitutive presence of personality in Descartes' metaphysics. In the process of studying the research literature, methodological guidelines are outlined in the form of the importance of personal determination of the search for truth, the key role of ethical motive and art as components of philosophizing. The thesis about the poetic form of presentation of metaphysics by Descartes as a form of fixation of its personal dimension is substantiated.

Keywords: metaphysics; Descartes; anthropology; reductionism; science; ethics; art

\section{Introduction}

Today, humanity is acutely in need of new worldviews. First of all, it is about realizing the consumption of the image of the world as the objective - reduced and impersonal one. Awareness of the demand for the world as a world of culture - of human values and meanings - comes to the fore. This condition is especially important for metaphysics as a basic sphere for fixing their metahistorical dimensions. In other words, it is about developing a modern version of metaphysics that is personality-oriented and rooted in personal experience. In this context, I draw attention to the axiom that underlies the assessment of the current state of culture. This refers to determining the influence on the way of its formation of Descartes' philosophical project. Its striking embodiment is the concept of Descartes' metaphysics as an apology of science (Moore, 2012). But in the process of in-depth understanding of this influence, it is difficult not to notice the contradiction between impersonal metaphysics and the demand of modern culture for personal meanings. On the surface there lies the contradiction about the impossibility of reconciling the existence of metaphysics and personality. But here it is necessary to take into account that, firstly, the appearance of simplicity and unambiguity is deceptive and, secondly, it is dangerous for humanity, because metaphysics is a form of preservation and reproduction of metahistorical values and meanings. A careful and unbiased vision of Descartes' legacy testifies to the importance and key significance of his personality for philosophy in general and metaphysics in particular. Until recently, in the research literature, Descartes was perceived as a meaningful continuation of the Plato and Aristotle's teaching concerning the vision of metaphysics as a set of depersonalized truths. Until recently, it was believed that this guideline was significantly strengthened in modern times due to the powerful influence of the doctrine of impersonal nature. That is why the vision of the incommensurability of modern metaphysics with anthropolo- 
gy seems convincing. For a long time, this incommensurability remained marginal, but in the twentieth century it came to the fore again and is the subject of intense debate. In recent years, attempts have been made to understand the role of the biographical factor in the philosophizing of Descartes, but the results achieved are not satisfactory to me. In particular, the obtained results need meaningful clarification and specification. The issue is the statement: "The axiomatics of Descartes' metaphysics are the foundations of his own faith" (transl. by A.M.) (Khoma, 2012, p. 32). The research literature that has appeared in recent years provides sufficient grounds for this. These are a collection of articles on Descartes' Treatise on Man (AntoineMahut, \& Gaukroger, 2016) and The Oxford Handbook of Descartes and Cartesianism (Nadler, Schmaltz, \& Antoine-Mahut, 2019). New perspectives are opened by my own conception of Cartesian metaphysics as metaphysical anthropology, based on the anthropologisation of his conception as the completion of the Copernican revolution (Khmil, \& Malivskyi, 2018; Malivskyi, 2019). I assess the current situation as a request for a constructive rethinking of the notion of the incompatibility of metaphysics and personality and the identification of the way of philosophizing that is its most complete embodiment. Therefore, my intention in this article is to consider the first philosophy of Descartes as a synthetic combination of metaphysics and the personality of the thinker.

\section{Purpose}

To consider the personal nature of Cartesian metaphysics. Its implementation involves a) outlining methodological changes in the philosophy of the twentieth century, b) analysis of ways to interpret anthropological component of philosophizing in Descartes studies and c) appeal to Descartes' texts to clarify the authentic form of his interpretation of metaphysics.

\section{Statement of basic materials}

Anticipating possible objections to the true significance of Descartes' legacy and the artificiality of his promotion to a number of great thinkers, I believe it appropriate to focus on the revolutions in Cartesian studies and its authoritative researcher Jean-Luc Marion. He emphasizes the key importance of the personality of his great countryman, whose legacy was studied by him for over forty years. In particular, Marion rightly points to the existence in European philosophy of a powerful tradition that has not received its verbal fixation yet. This refers to the movement "back to Descartes", which takes place at the turning points of European history. The researcher rightly emphasizes the connection between the fragmentary understanding of the father of modern philosophy and the desire of well-known thinkers to return to Descartes in the process of redefining the own coordinate system of philosophical thinking: "... great thinkers - from Kant to Heidegger, from Nietzsche to Wittgenstein - have always tried to go back to Descartes, to his questions, his answers, and his aporiae, in order to discover their own path of thought" (Marion, 2018, p. xxxii).

A significant obstacle is due to the fact that the thinker himself successfully hid his anthropological interest from the general public (Malivskyi, 2019). This fact prompts me, in the process of turning to his texts and research literature, to distance myself from their naive perception, because the image of the "mask" is often ignored. In this context, there grows the importance of those publications, the authors of which emphasize the key importance of personal guidance for the thinker. In particular, if for Hegel in the history of philosophy the paramount are the depersonalized forms of manifestation of the Absolute Idea, then for Dilthey - the personality of the 
thinker. Qualifying the originality of Cartesian metaphysics, Dilthey emphasizes the basic role of creative individuality, because his "metaphysics is an expression of his personality." It is difficult to resist the temptation to give a fuller Dilthey's emphasis on the originality and uniqueness of the creative figure of Descartes, which is expressed in his metaphysics. He "transfers his inherent heightened consciousness of the dignity and free power of the individual into sovereign selfconfidence... Everything harmonizes in this amazing person. His haughtiness. The proud seclusion of his life. The nobility of his language and the majestic, almost dramatic style of his works, completely permeated with the happiness of knowledge" (transl. by A. M.) (Dilthey, 2000, p. 260). As a meaningful concretization and deepening of these observations, I perceive the emphasis on the fact of the living presence of Descartes in his texts, which belongs to the poet and the thinker's compatriot - Paul Valéry. The latter emphasizes: «I love Descartes because of the simple and grandiose purity of his being, his firm thinking, the general impression of honesty and order, which is visible in his every action... attracts my mind ... his own presence in this 'prelude to philosophy'» (transl. by A. M.) (Razumovsky, 2014, p. 164).

To what extent is the fact of Descartes' living presence in his teaching taken into account by modern thinkers? Considering the question of how Descartes' philosophical revolution is interpreted in the literature of recent years, it is appropriate to focus primarily on postmodernism. This direction demonstrates the naive version of the answer to the question of the nature of the determining influence of the scientific revolution, which is still, to a large extent, uncritically setting priorities. In my opinion, postmodernism is important primarily as a representation of gains and losses on the path of long-term search for European anthropology. Its radical break with the Modernity age is axiomatic, and therefore it is appropriate to pay attention to the general denominator of the way postmodernists treat the vision of man by the representatives of Modernism. Ukrainian researcher Olga Sobol (2000) emphasizes their unanimity in the ironic attitude to the ambitious achievements of the previous era, namely - "to the ambitions of the metaphysics of Modernism as the only legitimate philosophy" (transl. by A. M.) (p. 90). The inflated claims of Modernity metaphysics are assessed as artificial and unfounded, because for them it is one of the many possible types of philosophizing that have been artificially privileged. The result is a problematization of the concepts of "reason" and "humanism" as key categories of European metaphysics. Concretizing the ways of expressing the phenomenon of man, postmodernists pay special attention to "ratiocentrism" and "anthropocentrism", supported by the "destructive selfconfidence of modern man" (transl. by A. M.) (Sobol, 2000, p. 98). It is significant for us that they connect the significant flaws of this period with the figure of R. Descartes. I believe that one of the most fateful assumptions that made it possible to "get out of the game" the way of philosophizing of the New Age is the man-made civilization demand. Its consequences include the absolutization of natural science rationality, an example of which is the technomorphic understanding of the metaphysical doctrine of Cartesius. Evidence of the prevalence of such a vision is its particular uncritical reproduction by the representative of postmodernism W. Welsch (2004): "with Descartes, a new type of instrumental mind came to power" (transl. by A. M.) (p. 90).

It is important for me to note that manifestations of uncritical reproduction of this reductionism in the interpretations of Descartes' philosophical revolution still take place. An example of their effectiveness in the literature of recent years is the monograph by Hanoch Ben-Yami "Descartes' Philosophical Revolution: A Reassessment". He notes in particular the paramount importance of the technological vision of the demand of the era (Ben-Yami, 2015, p. 8). A similar view is reproduced by the author of the "Descartes Dictionary" J. Cottingham (1993), who inter- 
prets physics as "the driving force of Descartes' philosophy" (p. 145). And since there are many such examples, it is advisable to pay attention to those stereotypes that still continue to define the spiritual landscape of our era. As noted above, among those significant obstacles that seem insurmountable is still the stereotype of the incompatibility of metaphysics with the doctrine of man.

This is a representative circumstance, the significance of which grows due to the authority of the prominent thinker. This refers to the fact mentioned by Heidegger in the first half of the twentieth century as the existence of dramatic tension between traditional metaphysics and philosophical anthropology. The eminent German philosopher, like his contemporaries Scheler and Cassirer, speaks not only of the absence in the modern age of answers to the fundamental question of what man is, but also of the absence of a methodology for understanding thereof. At the same time, he does not deviate far from Scheler's thoughts: "From no epoch has a man been so little hidden as from today..." (transl. by A. M.) (Heidegger, 2016, p. 32). In my opinion, there is an indisputable heuristic and constructive potential for his interpretation of metaphysics (or rather the impossibility to limit himself to the "school" vision of its nature and the insurmountable difficulties of its development on the basis of anthropology), which is fundamentally incapable of acting as a cornerstone: "And if real philosophy is metaphysics, then anthropology is completely incapable of laying the foundations of metaphysics" (transl. by A. M.) (Heidegger, 2016, p. 58).

Analysing the issue concerning the forms of reflection in the narratives of twentieth-century thinkers of anthropological intention and personality of Descartes, we must keep in mind, first, a narrow stereotype about its focus on the ideal of science, and secondly, its negative consequences in the form of reductionism. Among their manifestations are the identification of philosophy and science, fragmentary vision of man, the displacement of ethics, bias towards the personal dimensions of philosophizing.

In the process of meaningful overcoming of these shortcomings, the reasoning of well-known thinkers of the previous century on the essential differences between philosophy and science bear the heuristic value and significant methodological potential for me. It is especially valuable to emphasize the importance of the heuristic potential of art in the process of understanding the genesis of a new picture of the world. Let me remind you that among the heuristic positions there are the ideas of $\mathrm{K}$. Jaspers on the existential nature of art:

Philosophical metaphysics opens the philosopher an opportunity to see the truth in art forms..., ... Art itself becomes an existential function. Instead of being confined to a special world along with existence, it becomes a factor of self-enlightening unconditionality in a world of human openness. (transl. by A. M.) (Jaspers, 2012a, p. 374)

He emphasizes the consumptive use of metaphysics as a science and the impossibility of thus satisfying the need of modern man for philosophizing. It is extremely important that when considering what today's metaphysics might be like, Jaspers is one of those profound thinkers who appeals to the realm of art. Self-critically evaluating his own originality, he draws attention to 
Schelling's hitherto underestimated idea of art as a philosophical organon. The result of its deepening are the pages of the three-volume Jaspers' work "Philosophy", which deals with thinking in art as the only possible form of comprehension of transcendence. "Metaphysics, as the philosophy of art, is thinking in art, not about art; contemplation of art becomes for thinking an eye with which it looks at transcendence" (transl. by A. M.) (Jaspers, 2012b, p. 238). Later, Jaspers emphasizes his vision of metaphysical need as an attribute of human nature. It is important that the latter takes the form of man's need for art: "The urge of man's metaphysical thinking is towards art" (Jaspers, 2012b, p. 241).

And since one of the components of philosophizing in the last century was the "ethical vacuum", the origins of which are associated with the expansion of Descartes' reductionist teaching, the task of finding ways to overcome them constructively comes to the fore. The sound position is that of Hans Jonas (2001), the author of "ethics for technological civilization", who emphasizes the importance of overcoming this reductionism and restoring the category of "sacred" as an essential component of the human spirit (p. 45). Warning against the uncritical reproduction of naive-optimistic illusions, he also points to the danger of using "anthropocentric reduction" because it "contradicts the immanent purpose and the notable dignity of his [human] essence" (transl. by A. M.) (Jonas, 2001, p. 206). As it is evident from the previous statement, this refers to the expediency of deconstructing the established stereotypes about Descartes' teachings.

Successful attempts to constructively overcome the above-mentioned flaws of Descartes' philosophizing are demonstrated by the texts of the revolution participants in Cartesian studies, and foremost those by the above-mentioned Marion. For him, as a deep connoisseur of the legacy of his great countryman and the historical and philosophical process, his determining influence on the current philosophical landscape is axiomatic. Therefore, he considers it his priority to deconstruct the wide range of stereotypes that accompany the image of the great Descartes. For me, it is fundamental that in the process of realizing this task, Marion comes to understand the phenomenon of man. In particular, it relates to a distorted reception of the guidelines for a holistic vision of man by Descartes, which is perceived as a dualism of mind and body. The result of Marion's efforts to rehabilitate Descartes' legacy is a non-dualistic phenomenological conception of human existence that opens up new perspectives for philosophic historians.

Another version of the reconstruction of the anthropological and ethical motive of Descartes' philosophizing, hidden from the general public, which enables its reception as meaningfully related to the current demands, belongs today to Noa Naaman-Zauderer. In her monograph "Descartes' Deontological Turn: Reason, Will, and Virtue in the Later Writings" of 2010, she ambitiously declares a intention "to open up a new way of approaching a wide cluster of longdebated issues in Descartes' epistemology and ethics" (Naaman-Zauderer, 2010, p. 6). The subject of her critical rethinking is the established tradition of epistemology of Descartes' philosophizing, in which ethical views are understood as marginal, i.e. retrospectively added to epistemology and metaphysics. And since this deformation is unacceptable, the attempt of NaamanZauderer to turn this idea upside down is commendable. Rightly pointing to the priority of ethics for Descartes, the researcher in Chapter Six outlines the deep connection between epistemology and ethics in the second half of the forties. The originality of the position of the father of modern philosophy is associated with the ethical problem of the proper use of will. And since for Descartes the will, not the intellect, is the most important moment of human rationality, the main task is "the right use of free will". Among the most important derivatives is the recognition of the key role of faith in human nature, to which one of the main paragraphs is devoted 
(Naaman-Zauderer, 2010). Here the priority of faith over the natural light of the mind is substantiated both in the process of cognition and in the process of solving the problem of salvation. The innovation of the researcher's approach is especially obvious in the last two chapters, which deal with the concepts of "happiness" and "virtue" as the main purpose of our actions. At the same time, the thinker's priorities are quite strongly associated with virtues, because he "considers virtue not merely a means to happiness but rather our supreme good". Concretizing the Cartesian understanding of the human will as a manifestation of his godlikeness, Naaman-Zauderer (2010) emphasizes its intention as a focus on good and defends the thesis of unconditional dominance for the thinker of the supreme good (p. 175, p. 179), which is very reminiscent of Plato's "idea". As you can see, this emphasizes the importance of anthropological intent for the Descartes' searches. Herewith, the personal moment is ignored.

That is why Lawrence Renault's (2019) position on the importance of the personal basis of Descartes' ethics, recently published in the new Oxford Handbook in "Descartes' Moral Philosophy", is meaningfully close to me. There is no objection to the author's emphasis on the basic orientation of Descartes' philosophizing on the search for a reliable foundation for moral teaching. In the process of understanding the latter, the researcher's attention is drawn to the problem of the relationship between physics, metaphysics and ethics. A particularly valuable achievement of his publication is the attention to the main stages of the evolution of Descartes' philosophizing as the strengthening of personal motives. This is Lawrence's attention to the second half of the 1940s, which involved building a perfect ethic. The increasingly complete expression of the personal vision of ethics is expressed in the form of the transition from adoration of God to the moral based on virtue-passion of generosite, which manifests itself as the proper use of free will and "greatness of human being".

I see the undeniable heuristic potential in Lawrence Renault's innovative approach, which involves going beyond the notions of Descartes' subjectivism and recognizing the importance of the problem of "the other". Caring for the other, for his well-being and happiness is qualified by the researcher as a priority for the ethics of the great Frenchman. Here it is difficult not to see a meaningful refutation of the common thesis about Descartes' solipsism. As for the form of expression of morality and nobility, Renault justifiably evaluates it as altruism. And since the greatness of free will is qualified as the basis of Cartesian metaphysics, "the morality of generosity is rooted in metaphysics and represents its extreme development" (Renault, 2019). In the author's thoughts, it is easy to recognize both the indirect dialogue with Husserl on the originality of his claims to the development of the problem of intersubjective significance of human thinking, and the meaningful deepening of Marion's ideas.

One of the variants for emphasizing the importance of anthropological intention and personal choice as the basis of Descartes' philosophical legacy and the illusion of its reduction to the narrow framework of the naturalistic paradigm has been repeatedly voiced in recent years. This refers to an important problem for today in Cartesian reduced interpretations of the thinker's teachings and the emphasis on the basic role of freedom. In particular, J. Cottingham (2008) draws attention to the possibility of seeing a seeker and lover of truth behind the deceptive simplicity of the philosopher's texts in the traditional sense (p. 45). He also draws attention to the fact that his ethical provisions (in contrast to Kant) lack the imperative nature. It is a question of the need bequeathed to us of the personal choice of our own priorities between recourse to previous morality and belief in the unlimited possibilities of our mind. In the latter case, we have a great power over the world of nature and our own nature. And so the dramatic problem is, "whether we can 
hope to survive as a species without the help of a moral vision". In outlining it, the researcher goes beyond the instrumental reception of Descartes' teachings and emphasizes the meaningful rootedness of his morality in the previous tradition. "For Descartes, the requisite kind of moral vision was generated by Christian metaphysics, the objectivity of whose value system, for all his vaunted programme of doubt, he never seriously questioned" (Cottingham, 2008, p. 49). It is difficult to deny the legitimacy of this tension between the two outlined scenarios of future development in the teachings of Descartes. For me personally, the key opposition in this article between metaphysics and anthropology can be seen in this tension. To what extent is it overcome in the transition to the confrontation between science and art?

The recent opposition in the form of tension between the scientific and poetic components of the thinker's worldview has been the subject of research by Andrea Gadberry. She considers attention to the key role of the poetic principle in the work of the thinker to be a necessary precondition for going beyond the scientific reception of the "Cartesian cogito". The object of her close attention is the meaningful connotations of the Cartesian cogito, which remain unnoticed in the conditions of the dominance of its reduced image. Analysing the neglected forms of meaningful rootedness of cogito in sensuality, corporeality, human desires, the author emphasizes the importance of a holistic vision of Descartes' philosophical project. Therefore, as opposed to the teaching on extrasensory objectivity, Gadberry (2017) defends the key role of the poetic principle. It is, as she writes, about «the centrality of poetics to the project of the 'Meditations'» (p. 749).

In the process of searching for forms of a holistic vision of Descartes' inner world, it is important to pay attention to, as a rule, the neglected drama of human existence. Emphasizing the constitutive role of the poetic in the process of understanding the scientific revolution of the New Age, the author rightly warns against the dangers of simple solutions. It would seem that these include the literal perception of Descartes' words about his complete overcoming of sensuality and poetic vision of the world. But Gadberry, bearing in mind the authentic position of Descartes, rightly emphasizes the constitutive presence of the thinker in the outlined picture of the world. In particular, she rightly emphasizes the importance of "studying Cartesian poetics seriously", i.e. perceiving his strategy as a "poet-in-chief" (Gadberry, 2017, p. 749). Consistent with these ideas is the position of Kyo Lee, who, referring to the manifestations of human nature in Descartes works (about dreams, images, passions), argues the poetic worldview as a basic version of the interpretation of his philosophical project. It is, she writes, about the "Cartesian poetics of imagination" (Lee, 2013, p. 145).

But for me, these statements are still not convincing enough arguments about the key place of poetics in Descartes' worldview, because there are doubts about its significance for Descartes personally. Therefore, I think it is appropriate to draw attention to the connection between the analysis of the role of art in the way of philosophizing Descartes and his vision of the subject of philosophy. It is a proof of the existence of an immortal soul and the existence of God. Given the axiomatic inability of the methodology of the natural sciences to contribute to a meaningful clarification of the connection between God and the human soul, J.-L. Marion rightly emphasizes the meaningful kinship of poetic language and theology. And since Descartes' vivid identity, associated with the dominant status of poetry in his way of philosophizing, is still underestimated, he showing his respect for poets endows them with authority because "they bear witness to initial freedom of God in the encounter with the Fates". Emphasizing the originality of the heuristic and constructive potential of poetry, the modern French re- 
searcher notes that "in making new arguments, the conceptualization itself admit metaphors, images, and even theological arguments, which it had first rejected or of it had simply been unaware" (Marion, 2007, p. 115).

When considering the ways of interpreting Descartes' aesthetic views in modern literature, it is important to refrain from the temptation to consider them insignificant for him. Convincing arguments in favour of this thesis are the disproportionately small number of pages devoted to it and the neglected fact of their key significance for Descartes' worldview. Frederick de Buzon (2019) did not resist the ostensibility of these arguments in his article "The Compendium Musicae and Descartes's Aesthetics". But within this approach, the researcher ignores the importance of art and music for the thinker, as evidenced in particular by Cartesius' letter at the end of the article: "And if I die only of old age, I still would like some day to write on music theory" (Descartes, 1996, AT IV: 791). For me, these lines are strong evidence of the unconditional significance for Descartes of poetics as a form of presentation of his own metaphysics.

The opportunity to see the key significance and pervasive nature of the poetic project for Descartes' philosophizing provides an appeal to the way in which the basic provisions of his position are formed. Already the study of "Early Writings" testifies to the existence in the worldview of the thinker of paradoxical features that do not agree with the traditional vision of his determinism by the scientific revolution. This is about the openness to the world, a modest assessment of the possibilities of the theoretical mind, a high appreciation of image and art in the attainment of truth (Malivskyi, 2019). In the "Discourse on Method" a meaningful addition to the thesis of the key importance of art in the teachings of the thinker is the hierarchy of knowledge outlined by him, where the foundation is knowledge of man, while knowledge of nature is hypothetical. The outlined paradoxical vision of Descartes' worldview is still unconvincing and debatable in the current conditions. That is why the deep insight of one of the outstanding mathematicians and mechanics of the 19th century, Carl Gustav Jacobi, on the anthropological orientation of Descartes' search cannot fail to arouse admiration. It refers to his outlining the evolution of the inner world of the thinker, where the prominent place of anthropology largely determines his isolation and solitary way of life. "Noticing, however, to how few people he can report on these works, he turns from them to what he considers the supreme: to the study of man: but it turns out that most people know man even less than geometry, that is why he shrinks more and more into himself" (transl. by A. M.) (Jacobi, 1999, p. 1333).

It is important to me that the results obtained on the importance of poetics for the way of Descartes' philosophizing are confirmed in the pages of his works. Specifically, a careful attitude to them allows us to see that the widespread perception of the determining influence of science on the way of philosophizing and displacing art distorts his position. In particular, the pages of a famous letter to a French translator, published as a preface to the "Principles of Philosophy" of 1647, testify to the fact that he repeatedly used as synonymous the concepts of "knowledge" and "art" (le savoir, les arts) (Descartes, 1996, JSC IX: 2, 18). Convincing evidence of the importance of this moment for Descartes is the designating as art of "medicine and mechanics, and all the other arts" in one of the last paragraphs of the "Principles of Philosophy" (Descartes, 1996, AT VIIIA: 327). Outlining and meaningful understanding of these deep insights of the father of modern philosophy is beyond the scope of this article. The appeal to poetics as a form of understanding of Descartes' metaphysics opens new possibilities for understanding the first philosophy outlined by him as a synthetic combination of metaphysics and the personality of the thinker, where the latter is the cornerstone of the former. 


\section{Originality}

Based on Descartes' own concept of teaching, the author substantiates the personal nature of Cartesian metaphysics. Important prerequisites for its comprehension are attention to the ethical motive as the driving force of philosophizing and recognition of the importance of the poetic worldview. The idea of the basic role of poetics finds its meaningful confirmation in the texts of the philosopher, who interprets the main areas of philosophy (science, morality and medicine) as forms of art.

\section{Conclusions}

Based on his own vision of anthropology and metaphysics as the forms of completion of the revolution initiated by Copernicus, the author defends the idea of the constitutive presence of personality in Descartes' metaphysics. In the process of studying the research literature, methodological guidelines are outlined in the form of the importance of personal determination of the search for truth, the key role of ethical motive and art as components of philosophizing. The thesis about the poetic form of presentation of metaphysics by Descartes as a form of fixation of its personal dimension is substantiated.

\section{REFERENCES}

Antoine-Mahut, D., \& Gaukroger, S. (Eds.). (2016). Descartes' Treatise on Man and its Reception. In Studies in History and Philosophy of Science (Vol. 43). Springer. DOI: https://doi.org/10.1007/978-3-319-46989-8 (in English)

Ben-Yami, H. (2015). Descartes’ Philosophical Revolution: A Reassessment. Palgrave Macmillan. DOI: https://doi.org/ $10.1057 / 9781137512024$ (in English)

Buzon, F. de. (2019). The Compendium Musicae and Descartes’s Aesthetics. In S. Nadler, T. M. Schmaltz \& D. Antoine-Mahut (Eds.), The Oxford Handbook of Descartes and Cartesianism (pp. 254-268). Oxford University Press. DOI: https://doi.org/10.1093/oxfordhb/9780198796909.013.15 (in English)

Cottingham, J. (1993). A Descartes dictionary. Wiley-Blackwell. (in English)

Cottingham, J. (2008). Cartesian Reflections: Essays on Descartes' Philosophy. Oxford University Press. (in English)

Descartes, R. (1996). Oeuvres completes (Vol. 1-11). Paris: C. Adam et P. Tannery. (in French)

Dilthey, V. (2000). Vozzrenie na mir i issledovanie cheloveka so vremen Vozrozhdeniya $i$ Reformatsii. Universitetskaya kniga. (in Russian)

Gadberry, A. (2017). The Cupid and the Cogito: Cartesian Poetics. Critical Inquiry, 43(3), 738-751. DOI: https://doi.org/10.1086/691018 (in English)

Heidegger, M. (2016). Nemetskiy idealizm (Fichte, Schelling, Hegel) i filosofskaya problematika sovremennosti. Vladimir Dal. (in Russian)

Jacobi, C. G. (1999). On the life of Descartes and his method of rightly conducting the reason and seeking truth in the sciences. Uspekhi Fizicheskih Nauk, 169(12), 1332-1338. DOI: https://doi.org/10.3367/ UFNr.0169.199912g.1332 (in Russian)

Jaspers, K. (2012a). Filosofiya. Kniga pervaya. Filosofskoe orientirovanie v mire. A. K. Sudakov, Trans. Moscow: "Kanon+" ROOY "Reabylytatsyia". (in Russian)

Jaspers, K. (2012b). Filosofiya. Kniga tretya. Metafizika. A. K. Sudakov, Trans. Moscow: "Kanon+" ROOY "Reabylytatsyia". (in Russian)

Jonas, H. (2001). Das Prinzip Verantwortung. Versuch einer Ethik fur die technologische Zivilisation. Kyiv: Libra. (in Ukrainian)

Khmil, V., \& Malivskyi, A. (2018). The Problem of Forms of Completing the Copernicus Revolution in Modern Cartesian Science. Philosophy and Cosmology, 21, 131-139. DOI: https://doi.org/10.29202/PHILCOSM/21/14 (in English)

Khoma, O. (2012). Dekart i Paskal: Shliakh do filosofii na tli Grand Siècle. Filosofska dumka, 6, 19-38. (in Ukrainian) 
Lee, K. (2013). Reading Descartes Otherwise: Blind, Mad, Dreamy, and Bad. Fortham University Press. (in English)

Malivskyi, A. (2019). Neznanyi Dekart: Antropolohichnyi vymir u filosofuvanni. Dnipro: Herda. (in Ukrainian)

Marion, J.-L. (2007). On the Ego and on God: Further Cartesian Questions (Perspectives in Continental Philosophy). C. M. Gschwandtner, Trans. Fordham University Press. (in English)

Marion, J.-L. (2018). On Descartes’ Passive Thought: The Myth of Cartesian Dualism. C. M. Gschwandtner, Trans. University of Chicago Press. (in English)

Moore, A. W. (2012). The Evolution of Modern Metaphysics: Making Sense of Things. Cambridge University Press. (in English)

Naaman-Zauderer, N. (2010). Descartes’ Deontological Turn: Reason, Will, and Virtue in the Later Writings. Cambridge University Press. (in English)

Nadler, S., Schmaltz, T. M., \& Antoine-Mahut, D. (Eds.). (2019). The Oxford Handbook of Descartes and Cartesianism. Oxford University Press. DOI: https://doi.org/10.1093/oxfordhb/9780198796909.001.0001 (in English)

Razumovsky, I. S. (2014). Cartesian Studies of Paul Valery. Voprosy filosofii, 9, 156-169. (in Russian)

Renault, L. (2019). Descartess Moral Philosophy. In S. Nadler, T. M. Schmaltz \& D. Antoine-Mahut (Eds.), The Oxford Handbook of Descartes and Cartesianism (pp. 225-239). DOI: https://doi.org/10.1093/oxfordhb/ 9780198796909.013.13 (in English)

Sobol, O. (2000). Postmodern i maibutnie humanizmu. Humanizm: Suchasni interpretatsii ta perspektyvy (pp. 89-185). Kyiv. (in Ukrainian)

Welsch, W. (2004). Nash postmodernyi modern. A. L. Bohachov, M. D. Kultaieva, L. A. Sytnichenko, Trans. Kyiv: Alterpres. (in Ukrainian)

\section{LIST OF REFERENCE LINKS}

Descartes' Treatise on Man and its Reception / eds. by D. Antoine-Mahut, S. Gaukroger. Studies in History and Philosophy of Science. Springer, 2016. Vol. 43. 304 p. DOI: https://doi.org/10.1007/978-3-319-46989-8

Ben-Yami H. Descartes' Philosophical Revolution: A Reassessment. Palgrave Macmillan, 2015. 281 p. DOI: https://doi.org/10.1057/9781137512024

De Buzon F. Compendium Musicue and Descartes's Aestetics. The Oxford Handbook of Descartes and Cartesianism / eds. by S. Nadler, T. M. Schmaltz, D. Antoine-Mahut. Oxford University Press, 2019. P. 254-268.

Cottingham J. A Descartes dictionary. Wiley-Blackwell, 1993. 200 p.

Cottingham J. Cartesian Reflections: Essays on Descartes’ Philosophy. Oxford University Press, 2008. 352 p.

Descartes R. Oeuvres Complètes : in 11 vol. Paris : C. Adam et P. Tannery, 1996. 499 p.

Дильтей В. Воззрение на мир и исследование человека со времен Возрождения и Реформации. Университетская книга, 2000. 460 с.

Gadberry A. The Cupid and the Cogito : Cartesian Poetics. Critical Inquiry. 2017. Vol. 43. Iss. 3. P. 738-751. DOI: https://doi.org/10.1086/691018

Хайдеггер М. Немецикий идеализм (Фихте, Шеллинг, Гегель) и философская проблематика современности. Владимир Даль, 2016. 496 с.

Якоби К. Г. О жизни Декарта и его методе направлять ум правильно и изыскивать в науках истину. Успехи физических наук. 1999. T. 169. № 12. C. 1332-1338. DOI: https://doi.org/10.3367/UFNr.0169.199912g.1332

Ясперс К. Философия. Книга первая. Философское ориентирование в мире / пер. А. К. Судакова. Москва : "Канон+" РООИ "Реабилитация", 2012. 384 с.

Ясперс К. Философия. Книга третья. Метафизика / пер. А. К. Судакова. Москва : "Канон+" РООИ "Реабилитация", 2012. 296 с.

Йонас Г. Принциип відповідальності. У пошуках нової етики для технологічної ичивілізації. Київ : Лібра, 2001. $400 \mathrm{c}$.

Khmil V., Malivskyi A. The Problem of Forms of Completing the Copernicus Revolution in Modern Cartesian Science. Philosophy and Cosmology. 2018. Vol. 21. P. 131-139. DOI: https://doi.org/10.29202/PHILCOSM/21/14

Хома О. Декарт і Паскаль: шлях до філософії на тлі Grand Siècle. Філософська думка. 2012. № 6. С. $19-38$.

Lee K. Reading Descartes Otherwise: Blind, Mad, Dreamy and Bad. Fortham University Press, 2013. 219 p.

Малівський А. Незнаний Декарт: антропологічний вимір у філософуванні. Дніпро : Герда, 2019. 300 с. 
Marion J.-L. On the Ego and on God: Further Cartesian Questions (Perspectives in Continental Philosophy) / trans. by C. M. Gschwandtner. Fordham University Press, 2007. 488 p.

Marion J.-L. On Descartes' Passive Thought: The Myth of Cartesian Dualism / transl. by C. M. Gschwandtner. University of Chicago Press, 2018. 304 p.

Moore A. W. The Evolution of Modern Metaphysics: Making Sense of Things. Cambridge University Press, 2012. $668 \mathrm{p}$.

Naaman-Zauderer N. Descartes’ Deontological Turn: Reason, Will, and Virtue in the Later Writings. Cambridge University Press, 2010. $236 \mathrm{p}$.

The Oxford Handbook of Descartes and Cartesianism / eds. by S. Nadler, T. M. Schmaltz, D. Antoine-Mahut. Oxford University Press, 2019. DOI: https://doi.org/10.1093/oxfordhb/9780198796909.001.0001

Разумовский И. С. Картезианские студии Поля Валери. Вопросы философии. 2014. № 9. С. $156-169$.

Renault L. Descartes moral philosophy. The Oxford Handbook of Descartes and Cartesianism / eds. by S. Nadler, T. M. Schmaltz, D. Antoine-Mahut. Oxford University Press, 2019. P. 225-239. DOI: https://doi.org/ 10.1093/oxfordhb/9780198796909.013.13

Соболь О. Постмодерн і майбутнє гуманізму. Гуманізм: сучасні інтерпретаиії та перспективи. Київ, 2000. C. 89-185.

Вельш В. Наш постмодерний модерн / пер. А. Л. Богачова, М. Д. Култаєвої, Л. А. Ситніченко. Київ : Альтерпрес, 2004. 328c.

\title{
А. М. МАЛІВСЬКИЙ ${ }^{1 *}$ \\ ${ }^{1 *}$ Дніпровський національний університет залізничного транспорту імені академіка В. Лазаряна (Дніпро, Україна), ел. пошта telepat-57@ukr.net, ORCID 0000-0002-6923-5145
}

\section{ОСОБИСТІСНА МЕТАФІЗИКА КАРТЕЗІЯ}

Мета. Основною метою статті є дослідження особистісної природи картезіанської метафізики. Ї̈і реалізація передбачає: а) окреслення методологічних зрушень в філософії XX століття; б) аналіз способів тлумачення в декартознавсті антропологічної компоненти філософування; в) звернення до текстів Декарта для уточнення автентичної форми тлумачення ним метафізики. Теоретичний базис. Свій погляд на спадщину Декарта я засновую на концептуальних положеннях феноменології, екзистенціалізму та герменевтики. Наукова новизна. Виходячи з власної концепції вчення Декарта, автор обгрунтовує особистісний характер картезіанської метафізики. Важливими передумовами іiі осягнення є увага до етичного мотиву як рушійної сили філософування та визнання значущості поетичного світосприйняття. Ідея базової ролі поетики знаходить своє змістовне підтвердження в текстах філософа, який тлумачить основні сфери філософії (науку, мораль та медицину) як форми прояви мистецтва. Висновки. Спираючись на власне бачення антропології та метафізики як форм завершення розпочатої Коперником революції, автор обстоює ідею конститутивної присутності особистості в метафізиці Декарта. В процесі вивчення дослідницької літератури окреслюються методологічні оріснтири у вигляді важливості особистого виміру шукань істини, ключової ролі етичного мотиву та мистецтва як компоненти філософування. Обгрунтовується теза про поетичну форму викладу метафізики у Декарта як форму фіксації ії особистісного виміру.

Ключові слова: метафізика; Декарт; антропологія; редукціонізм; наука; етика; мистецтво

\author{
А. Н. МАЛИВСКИЙ ${ }^{1 *}$ \\ ${ }^{1 *}$ Днипровский национальный университет железнодорожного транспорта имени академика В. Лазаряна \\ (Днипро, Украина), эл. почта telepat-57@ukr.net, ORCID 0000-0002-6923-5145
}

\section{ЛИЧНОСТНАЯ МЕТАФИЗИКА КАРТЕЗИЯ}

Цель. Основной целью статьи является изучение личностного характера картезианской метафизики. Ее реализация предполагает: а) фиксацию методологических сдвигов в философии XX века; б) анализ способов интерпретации антропологической составляющей философствования в декартоведении; в) обращение к тек- 
стам Декарта для уточнения аутентичной формы изложения им собственной метафизики. Теоретический базис. Свой подход я базирую на концептуальных положениях феноменологии, экзистенциализма и герменевтики. Научная новизна. Исходя из собственной концепции учения Декарта, автор обосновывает личностный характер картезианской метафизики. Важными предпосылками ее постижения являются внимание к этическому мотиву как движущей силе философствования и признание значимости поэтического восприятия. Идея базисной роли поэтики находит свое содержательное подтверждение в текстах философа, который истолковывает основные сферы философии (науку, мораль и медицину) как формы проявления искусства. Выводы. Опираясь на собственное понимание антропологии и метафизики как форм завершения революции Коперника, автор обосновывает идею конститутивного присутствия личности в метафизике Декарта. В процессе изучения исследовательской литературы обрисовываются методологические ориентиры в виде важности личностного измерения искания истины, ключевой роли этического мотива и искусства как компонента философии. Обосновывается идея важности для нас поэтической формы изложения метафизики как способа фиксации личностного измерения метафизики Декарта.

Ключевые слова: метафизика; Декарт; антропология; редукционизм; наука; этика; искусство

Received: 16.10 .2019

Accepted: 07.05.2020 